\title{
PENINGKATAN KEMAMPUAN KOMUNIKASI MATEMATIS SISWA MELALUI MODEL PEMBELAJARAN INSIDE OUTSIDE CIRCLE (IOC) DENGAN MENGGUNAKAN MEDIA CBC (CUBE BEAM COLOR)
}

\author{
Ri'ayatul Khoiriyah ${ }^{\mathrm{a}}$, Ali Shodikin ${ }^{\mathrm{b}}$, Heny Ekawati Haryono \\ a JurusanPendidikan Matematika, Universitas Islam Darul 'Ulum Lamongan \\ J1. Airlangga No.3 Sukodadi Lamongan, khoiriyahiturya@ gmail.com \\ b JurusanPendidikan Matematika, Universitas Islam Darul 'Ulum Lamongan \\ Jl. Airlangga No.3 Sukodadi Lamongan, alishodikin@unisda.ac.id \\ c JurusanPendidikan Matematika, Universitas Islam Darul 'Ulum Lamongan \\ J1. Airlangga No.3 Sukodadi Lamongan, henny@unisda.ac.id
}

\begin{abstract}
Abstrak
Penelitian ini dilatarbelakangi oleh kesulitan siswa dalam menyampaikan suatu konsep. Hal ini dikarenakan peran matematika sebagai bahasa simbolik yang memungkinkan terwujudnya komunikasi secara cermat dan tepat. Tujuan penelitan ini untuk mengetahui perbedaan dan mana yang lebih baik antara model pembelajaran kooperatif Inside Outside Circle (IOC) dengan menggunakan media CBC (Cube Beam Color) untuk meningkatkan kemampuan komunikasi matematis siswa pada pokok bahasan kubus dan balok di kelas VIII MTs Islamiyah Tulungagung. Penelitian ini merupakan penelitian kuantitatif, dengan metode penelitian ini Quasy Experimental dan desain penelitian The Non-Equivalent Control Group Design. Subjek penelitian ini adalah 46 siswa yang terdiri 24 siswa kelompok eksperimen dan 22 siswa kelompok kontrol yang diperoleh dengan teknik Cluster Random Samplingpada kelas VIII. Instrumen diberikan berupa tes uraian yang terdiri dari 3 soal dan wawancara. Berdasarkan hasil penelitian disimpulkan bahwa kelas eksperimen lebih baik dari kelas kontrol. Hasil ini terlihat dari setelah dilakukan uji Ngaindiperoleh $t_{\text {tabel }}=2,015>t_{\text {hitung }}=31,298$, dengan demikian $H_{0}$ ditolak dan $H_{1}$ diterima. Didapatkan nilai rata-rata hasil belajar mengalami peningkatan untuk kelas eksperimen sebesar 70,12\% kategori tinggi sedangkan kelas kontrol sebesar 53,43\% kategori sedang. Hasil pretest analisis statistik uji-t diperoleh hasil $P_{\text {value }}$ adalah $0,798>0,05$ yang berarti tidak terdapat perbedaan yang signifikan antara kemampuan komunikasi matematis siswa kelas eksperimen dan siswa kelas kontrol, sedangkan dari hasil posttest $\operatorname{diperoleh} P_{\text {value }}$ adalah $0,003 \leq 0,05$, dengan demikian, $H_{0}$ ditolak dan $H_{1}$ diterima yang berarti terdapat perbedaan kemampuan komunikasi yang signifikan antara kelas eksperimen dan kontrol, dapat disimpulkan bahwa terdapat perbedaan yang signifikan antara kemampuan komunikasi matematis yang diajar dengan menggunakan Model Pembelajaran Inside Outside Circle dengan menggunakan media CBC (Cube Beam Color) dengan siswa yang diajar menggunakan pembelajaran konversional pada pokok bahasan kubus dan balok.
\end{abstract}

Kata Kunci: Model Inside Outside Circle (IOC), CBC (Cube Beam Color), Kemampuan Komunikasi Matematis

Abstract

This research is motivated by students' difficulties in conveying a concept. This is because the role of mathematics as a symbolic language that allows the realization of communication accurately and precisely. The purpose of this research is to find out the difference and which is better between Inside OutsideCircle (IOC) cooperative learning model using CBC media (Cube Beam Color) to improve students' mathematical communication skills on the subject of cubes and 
beams in class VIII MTs Islamiyah Tulungagung. This research is quantitative research, with this research method Quasy Experimental and research design The Non-Equivalent Control Group Design. The subjects of this study were 46 students consisting of 24 experimental group students and 22 control group students obtained by Cluster Random Sampling technique in class VIII. The instrument was given in the form of a description test consisting of 3 questions and an interview. Based on the results of the study it was concluded that the experimental class was better than the control class. This result can be seen from after the $\mathrm{N}$-gain test is obtained t_table $=2.015>\mathrm{t} \_$count $=31.298$, thus $H_{0}$ is rejected and $H_{1}$ is accepted. Obtained an average value of learning outcomes has increased for the experimental class of $70.12 \%$ in the high category while the control class is $53.43 \%$ in the medium category. The results of the t-test statistical analysis pretest obtained $P_{\text {value }}$ result is $0.798>0.05$, which means there is no significant difference between the mathematical communication skills of experimental class students and control class students, whereas the posttest results obtained $P_{\text {value }}$ is $0.003 \leq 0.05$, thus, $H_{0}$ is rejected and $H_{1}$ is accepted which means there are significant differences in communication skills between the experimental and control classes, it can be concluded that there is a significant difference between the mathematical communication skills taught using the Inside Outside Circle Learning Model using CBC media (Cube Beam Color)with students taught using conversion learning on the subject of cubes and beams.

Keywords: Inside Outside Circle (IOC) Model, CBC (Cube Beam Color),Ability Mathematical Communication

\section{PENDAHULUAN}

Matematika sebagai salah satu mata pelajaran dasar pada setiap jenjang pendidikan formal, mempunyai peranan yang sangan penting didalam pendidikan. Menurut Menteri Pendidikan Nasional No. 22 Tahun 2006 disebutkan tentang tujuan pembelajaran matematika untuk semua jenjang pendidikan dasar dan menengah adalah agar siswa mampu: 1) memahami konsep matematika, menjelaskan keterkaitan antara konsep matematika secara luwes, akurat, efisien dan tepat dalam pemecahan masalah; 2) menggunakan penalaran pada pola dan sifat, melakukan manipulasi matematika dalam membuat generalisasi, menyusun bukti, atau menjelaskan gagasan dan pernyataan matematika; 3) memecahkan masalah yang meliputi kemampuan memahami masalah, merancang model matematika, menyelesaikan model, dan menafsirkan solusi yang diperoleh; 4) mengomunikasikan gagasan dengan simbol, tabel, diagram, atau media lain untuk memperjelas keadaan atau masalah; 5) memiliki sikap menghargai kegunaan matematika dalam kehidupan yaitu rasa ingin tahu, perhatian, dan minat dalam mempelajari matematika, serta ulet dan percaya diri dalam pemecahan masalah.

Pada tujuan pembelajaran matematika yang pertama menurut Peraturan Menteri Pendidikan Nasional No. 22 Tahun 2006 yaitu tentang mengomunikasikan gagasan dengan simbol, tabel, diagram, atau media lain untuk memperjelas keadaan atau masalah. 
Komunikasi adalah kemampuan siswa dalam menyampaikan atau menerima gagasan, sehingga terjadi proses belajar (Rachmayani, 2014). Komunikasi dalam pembelajaran matematika memiliki peran yang cukup penting. Ketika terjadi diskusi antar siswa kemampuan komunikasi sangat penting, dimana siswa diharapkan mampu menyatakan, menjelaskan, mengambarkan, mendengar, menanyakan dan bekerja sama sehingga dapat membawa siswa pada pemahaman yang mendalam tentang matematika.

Istilah komunikasi diadopsi dari bahasa inggris yaitu "communication" (Harapan \& Ahmad., 2014). Istilah ini berasal dari bahasa latin "communicare" yang bermakna membagi sesuatu dengan orang lain, memberikan sebagian untuk seseorang, tukar menukar, memberitahukan sesuatu kepada seseorang, bercakap-cakap, bertukar pikiran, berhubungan, berteman, dan lain sebagainya. NCTM menyatakan bahwa komunikasi matematis adalah satu kompetensi dasar matematikayang esensial dari matematika dan pendidikan matematika (Ansari, 2016). Tanpa komunikasi yang baik, maka perkembangan matematika akan terhambat. Simbol merupakan lambang atau media yang mengandung maksud dan tujuan tertentu. Simbol komunikasi ilmiah dapat berupa tabel, bagan, grafik, gambar persamaan matematika dan sebagainya.

Berdasarkan observasi di lapangan, kenyataannya banyak siswa yang mengalami kesulitan dalam memahami matematika. Di lain pihak, siswa yang cerdas dalam matematika seringkali kurang mampu menyampaikan hasil pemikirannya. Mereka kurang mampu berkomunikasi dengan baik, seakan yang mereka pikirkan hanya untuk dirinya sendiri. Selain itu siswa juga belum tentu memahami informasi yang mereka terima terkait konsep matematika karena karakteristik matematika yang sarat dengan istilah dan simbol.

Inside Outside Circle adalah model pembelajaran dengan sistem lingkaran kecil dan lingkaran besar yang di awali dengan pembentukan kelompok besar dalam kelas yang terdiri dari kelompok lingkaran dalam dan kelompok lingkaran luar (Shoimin, 2014). Anggota kelompok lingkaran luar berdiri menghadap ke dalam. Antara anggota lingkaran dalam dan luar saling berpasangan dan berhadap-hadapan, di mana siswa saling membagi informasi pada saat yang bersamaan dengan pasangan yang berbeda dengan singkat dan teratur. Kemudian, siswa berada di lingkaran kecil diam di tempat, sementara siswa yang berada di lingkaran besar bergeser satu atau 
dua langkah searah jarum jam sehingga masing-masing siswa mendapat pasangan baru.

Khaeruddin (2018) mengatakan bahwa model pembelajaran Inside Outside Circle (IOC) dapat menunjukkan aktivitas guru dan siswa mengalami peningkatan hasil belajar siswa dilihat dari penerapan pada siklus I nilai rata-rata sebesar 62,5 dengan presentase ketuntasan klasikal mencapai 25\%. Nilai ketuntasan belajar klasikal ini masih kurang juga dari standar yang ditetapkan yaitu 65. Pada akhir siklus II nilai rata-rata adalah 71 dengan presentase ketuntasan klasikal 90\%. Hal ini dapat dilihat dari ketuntasan belajar yang telah ditetapkan disekolah yaitu siswa dikatakan tuntas apabila mencapai nilai $>65$.

Indikator kemampuan komunikasi matematis yang dipakai dalam penelitian ini menurut Kementrian pendidikan Ontario tahun 2005 (Hendriana, dkk., 2017), ada tiga macam yaitu: (1) Written text yaitu pemberian jawaban dengan menggunakan bahasa sendiri, membuat model situasi atau persoalan menggunakan lisan, tulisan konkret. (2) Drawing yaitu merefleksikan benda-benda nyata, gambar, dan diagram ke dalam ide matematika. (3) Mathematical expressions yaitu mengekspresikan konsep matematika dengan menyatakan peristiwa sehari-hari dalam bahasa atau simbol matematika.

Berdasarkan uraian permasalahan tersebut, peneliti menerapan model pembelajaran yang melibatkan siswa secara aktif dan meningkatkan komunikasi matematis dalam proses pembelajaran melalui model pembelajaran Inside Outside Circle (IOC) dimana siswa bekerjasama secara kelompok kecil 4-5 siswadiberi waktu untuk berdiskusi, setelah mereka berdiskusi, guru meminta kelompok luar dan kelompok dalam maju kedepan untuk berdiskusi kepada anggota kelompok. Lingkaran dalam bergerak berlawanan arah dengan anggota kelompok lingkaran luar berdiri menghadap ke dalam dan lingkaran dalam berdiri melingkar menghadap keluar, tiap-tiap pasangan yang berhadapan disebut kelompok pasangan asal. Setiap pergerakan akan membentuk pasangan baru. Pasangan ini wajib memberi informasi berdasarkan hasil diskusi dengan pasangan asal, sehingga hasil diskusi di tiap-tiap kelompok besar tersebut kemudian dipaparkan sehingga terjadi diskusi antar kelompok besar. Selain model pembelajaran Inside Outside Circle (IOC) juga dengan menggunakan media CBC (Cube Beam Color) sehingga dapat membantu siswa dalam memahami konsep Kubus dan Balok dengan cara jaring-jaring yang telah 
berbentuk kubus dan balok di isi dengan kertas manila warna yang sudah dibentuk kubus-kubus kecil sebanyak besar jaringjaring kubus dan balok, banyaknya kubus kecil yang masuk ke dalam jaring-jaring kubus atau balok disebut volume, dan banyak kubus yang terlihat pada sisi jaringjaring kubus dan balok disebut luas.

\section{METODE PENELITIAN}

Metode yang digunakan dalam penelitian ini merupakan kuantitatif, karena data yang dikumpulkan berupa angka dan proses pengolahan data pengujian hipotesis dengan analisis statistik yang bersesuaian. Jenis penelitian ini menggunakaQuasy Experimental dengan desain penelitian the Non-Equivalent Control Group Design (Sugiono, 2014). Subjek dalam penelitian ini adalah 46 siswa yang terdiri dari 24 siswa kelompok eksperimen dan 22 siswa kelompok kontrol yang diperoleh dengan teknik Cluster Random Sampling pada kelas VIII. Instrumen yang diberikan berupa tes uraian yang terdiri dari 3 soal dan wawancara 4 subjek.

Tes dalam penelitian ini dibagi menjadi 2, yaitu pretes dan posttest. Pretes bertujuan untuk mengetahui kemampuan komunikasi matematis siswa sebelum mendapat perlakuan, sedangkan posttest bertujuan untuk mengetahui kemampuan komunikasi matematik siswa sesudah mendapat perlakuan.

Instrumen yang baik harus memenuhi dua persyaratan, yaitu valid dan reliabel. Valid adalah instrumen tersebut dapat digunakan untuk mengukur apa yang seharusnya diukur. Sedangkan intrumen reliabel adalah instrumen yang bisa digunakan beberapa kali untuk untuk mengukur objek yang sama, akan menghasilkan data yang sama.

Tabel 1 Hasil Uji Validitas

\begin{tabular}{|c|c|c|c|}
\hline $\begin{array}{c}\text { No. } \\
\text { Soal }\end{array}$ & $\boldsymbol{r}_{\text {hitung }}$ & $\boldsymbol{r}_{\text {tabel }}$ & $\begin{array}{c}\text { Keterang } \\
\text { an }\end{array}$ \\
\hline 1. & 0,489 & 0,3961 & Valid \\
\hline 2. & 0,437 & 0,3961 & Valid \\
\hline 3. & 0,485 & 0,3961 & Valid \\
\hline
\end{tabular}

Tabel 2

Hasil Uji Reabilitas Instrumen

Reliability Statistics

\begin{tabular}{|c|c|}
\hline $\begin{array}{c}\text { Cronbach's } \\
\text { Alpha }\end{array}$ & N of Items \\
\hline ,646 & 4 \\
\hline Berdasarkan Tabel 2 diketahui
\end{tabular}

bahwa nilai cronbach alpha $=0,646$. Ini berarti bahwa nilai cronbach alphaantara $0,50-0,70$. Dengan demikian, data ini dinyatakan reliabel yang mempunyai tingkatan sedang.

Selain uji validitas, reliabel masih ada analisis uji yang lain yaitu uji normalitas, uji homogenitas,uji korelasi , uji N-gain dan uji hipotesis. 
ANALISIS DATA DAN PEMBAHASAN

Kelas yang digunakan penelitian adalah kelas VIII B sebagai kelas eksperimen dengan jumlah siswa 24 siswa dan kelas VIII A sebagai kelas kontrol yang jumlah siswa 22 siswa. Pada penelitian ini kelas eksperimen yang terdiri dari 24 siswa diajarkan menggunakan model pembelajaran Inside Outside Circle (IOC), sedangkan kelas kontrol yang terdiri dari 22 siswa diajarkan menggunakan pembelajaran konvensional.

Pada proses pembelajaran peneliti mengambil materi matematika yang tentang materi bangun ruang kubus dan balok. Sebelum proses pembelajaran dimulai peneliti ingin melihat kemampuan komunikasi matematik siswa dengan memberikan pretes beruapa soal uraian dengan 3 butir soal. Rata-rata kemampuan komunikasi matematik siswa kelas eksperimen dan kontrol hampir sama. Setelah dilakukan pretes dan analisis data kemudian dilakukan proses belajar mengajar pada kelas ekperimen dan kelas kontrol. Pada pertemuan ke-5 dilakukan postes untuk melihat apakah ada peningkatan setelah diberikan perlakuan terhadap model pembealajaran tersebut.

Setelah data terkumpul, kemudian data tersebut dianalisis. Berikut ini disajikan deskripsi dan analisis data kemampuan komunikasi matematis yang diberikan kepada siswa kelas eksperimen dan kelas kontrol.

Tes hasil kemampuan komunikasi matematis siswa kelas eksperimen sebelum dilakukan pembelajaran dengan menggunakan model pembelajaran Inside Outside Circle (IOC) dengan menggunakan media CBC (Cube Beam Color) memiliki nilai terendah yakni 26 sedangkan nilai tertinggi yakni 54diperoleh nilai rata-rata 38,00, sedangkan pembelajaran dengan menggunakan model pembelajaran konvensional memiliki nilai terendah yakni 22 sedangkan nilai tertinggi yakni 51, diperoleh nilai rata-rata 37,04.

Tes hasil kemampuan komunikasi matematis siswa kelas eksperimen sesudah dilakukan pembelajaran dengan menggunakan model pembelajaran Inside Outside Circle (IOC) dengan menggunakan media CBC (Cube Beam Color) memiliki nilai terendah yakni 66 dan nilai tertinggi sebesar 89 diperoleh nilai rata-rata 77,67, sedangkan model pembelajaran konvensional memiliki nilai terendah yakni 57sedangkan nilai tertinggi yakni 86 diperoleh nilai rata-rata 70,95.

Diketahui bahwa nilai tertinggi siswa dikelas eksperimen lebih tinggi dari pada siswa di kelas kontrol, sedangkan nilai terendah di kelas eksperimen lebih besar 
9angka dibanding kelas kontrol. Nilai ratarata siswa kelas eksperimen lebih tinggi dibandingkan nilai rata-rata siswa di kelas kontrol dengan selisih 6,72.

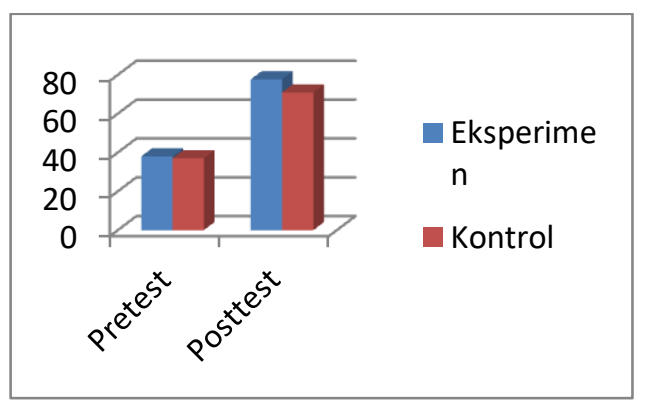

\section{Gambar 1}

\section{Histogram Perbedaan Distribusi Kelas Eksperimen dan Kontrol}

\section{Analisis Data}

Analisis data yang digunakan dalam penelitian ini adalah uji beda menggunakan uji Independent T-Test.Pada proses pengolahan data diperlukan beberapa uji prasyarat analisis dalam melakukan pengujian hipotesis terhadap variabelvariabel yang diteliti. Adapaun syaratsyarat yang harus dipenuhi sebagai berikut: Uji Normalitas digunakan untuk melihat data yang diujikan berdistribusi normal atau tidak. Data yang digunakan diambil dari hasil pretest pada kelas eksperimen dan kontrolkritesria yaitu bila taraf signifikansi (sig) $\geq 0,05$, maka $H_{0}$ diterima, berarti data normal. Jika taraf signifikansi (sig) $\leq 0,05$, maka $H_{0}$ ditolak, berarti data tidak normal. Berikut ini adalah tabel hasil analisis uji normalitas data pretest.
Tabel 3

\section{Uji Normalitas Data Pretest}

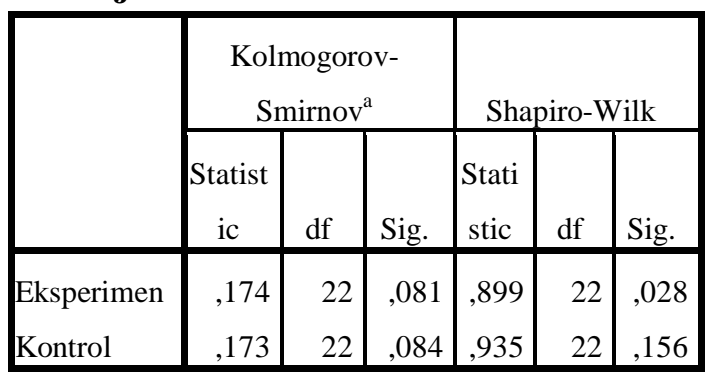

a. Lilliefors Significance Correction

Berdasarkan Tabel 3 diketahui bahwa nilai signifikan dari kelas eksperimenadalah $\quad 0,081$. Sehingga diperoleh nilai signifikan $0,081 \geq 0,05$, dan kelas kontrol adalah 0,084 diperoleh nilai signifikan $0,084 \geq 0,05$, karena nilai signifikan dari data kelas eksperimenlebih besar dari taraf signifikan 0,05, maka data kelas eksperimen dan kontrol berdistribusi normal.

Uji homogenitas berfungsi untuk menguji apakah kedua sampel memiliki varian yang sama atau tidak. Data yang digunakan diambil dari hasil pretest pada kelas eksperimen dan kelas kontrol.

Tabel 4

Uji Homogenitas Data Pretest

\begin{tabular}{|r|r|r|r|}
\hline $\begin{array}{l}\text { Levene } \\
\text { Statistic }\end{array}$ & df1 & \multicolumn{1}{c|}{ df2 } & \multicolumn{1}{c|}{ Sig. } \\
\hline 3,462 & 6 & 13 &, 029 \\
\hline
\end{tabular}

Berdasarkan Tabel 4 diketahui bahwa nilai signifikan $=0,029$. Sehingga nilai signifikasn $=0,029 \geq 0,05$. Karena nilai signifikan dari data tersebut lebih 
besar dari taraf signifikan 0,05 maka data tersebut dinyatakan homogen.

Uji normalitas digunakan untuk melihat data yang diujikan berdistribusi normal atau tidak. Data yang digunakan diambil dari hasil postest pada kelas eksperimen dan kontrolkritesria yaitu bila taraf signifikansi $(\mathrm{sig}) \geq 0,05$, maka $H_{0}$ diterima, berarti data normal. Jika taraf signifikansi $(\mathrm{sig}) \leq 0,05$, maka $H_{0}$ ditolak, berarti data tidak normal. Berikut ini adalah tabel hasil analisis uji normalitas data protest.

Berdasarkan uji hipotesis pretest diperoleh nilai sig (2-tailed) atau $P_{\text {value }}$ adalah 0,798, sehingga dapat dituliskan nilai sig (2-tailed) atau $P_{\text {value }}>$ taraf $\operatorname{signifikan}(0,05=5 \%)=0,798<0,05$.

Ini berarti bahwa nilai $P_{\text {value }}$ lebih besar dari pada taraf signifikan 5\%. Dengan demikian, $H_{0}$ diterima dan $H_{1}$ ditolak yang berarti tidak terdapat perbedaan yang signifikan antara rata-rata pretest kemampuan komunikasi matematis yang diajar dengan menggunakan Model Pembelajaran Inside Outside Circle dengan menggunakan media $\mathrm{CBC}$ (Cube Beam Color) dengan siswa yang diajar dengan menggunakan pembelajaran konversional.

Diperoleh bahwa nilai signifikan dari kelas eksperimen adalah 0,107. Sehingga diperoleh nilai signifikan
$0,107 \geq 0,05, \quad$ dan kelas kontrol adalah 0,053 diperoleh nilai signifikan $0,053 \geq$ 0,05, karena nilai signifikan dari data kelas eksperimenlebih besar dari taraf signifikan 0,05, maka data kelas eksperimen dan kontrol berdistribusi normal.

Uji homogenitas berfungsi untuk menguji apakah kedua sampel memiliki varian yang sama atau tidak. Data yang digunakan diambil dari hasil posttest pada kelas eksperimen dan kelas kontrol.

Tabel 5

Uji Homogenitas Data Posttest

\begin{tabular}{|r|r|r|r|}
\hline Levene Statistic & df1 & df2 & \multicolumn{1}{c|}{ Sig. } \\
\hline 2,059 & 5 & 14 &, 132 \\
\hline
\end{tabular}

Berdasarkan Tabel 5. diketahui bahwa nilai signifikan $=0,132$. Sehingga nilai signifikasn $=0,132 \geq 0,05$. Karena nilai signifikan dari data tersebut lebih besar dari taraf signifikan 0,05 maka data tersebut dinyatakan homogen.

Uji hipotesis dengan kaidah pengujiandicantumkan pada penjelasan diatas, menunjukkan bahwa variabel dalam penelitian tersebut memenuhi persyaratan kelayakan untuk dapat diujikan lebih lanjut. jika nilai sig (2-tailed) $\geq 0,05$ atau $H_{0}$ diterima jika nilai sig (2-tailed) atau $P_{\text {value }}<\left(0,05\right.$ atau 5\%) maka $H_{0}$ ditolak. Berikut ini adalah tabel hasil analisis uji hipotesis data posttest.

Berdasarkan uji hipotesis diketahui bahwa nilai sig (2-tailed) atau $P_{\text {value }}$ adalah 
0,03 , sehingga dapat dituliskan nilai sig (2tailed $)$ atau $P_{\text {value }}>$ taraf signifikan $(0,05=$ $5 \%)=0,03<0,05$. Ini berarti bahwa nilai $P_{\text {value }}$ lebih kecil dari pada taraf signifikan 5\%. Dengan demikian, $H_{0}$ ditolak dan $H_{1}$ diterima yang berarti terdapat perbedaan yang signifikan antara rata-rata posttest kemampuan komunikasi matematis yang diajar dengan menggunakan Model Pembelajaran Inside Outside Circledengan menggunakan media $\mathrm{CBC}$ (Cube Beam Color) dengan siswa yang diajar dengan menggunakan pembelajaran konversional Berdasarkan pengolahan hasil pretest dan posttest kelas eksperimen dan kelas kontrol dapat dilihat dari N-Gain (peningkatan) kemampuan komunikasi matematis siswa. Dan rata-rata nilai pretest dan posttesttersebut dapat diketahui bahwa ada peningkatan kemampuan komunikasi matematis siswa baik kelas eksperimen maupun kelas kontrol yang dapat dilihat pada tabel berikut:

Tabel 6

Data N-Gain Kemampuan Komunikasi Matematis

\begin{tabular}{|l|c|r|c|}
\hline \multicolumn{1}{|c|}{ Kelas } & N-Gain & $\begin{array}{c}\text { Persentase } \\
\boldsymbol{\%}\end{array}$ & Kriteria \\
\hline Eksperimen & 0,701246762 & $70,12 \%$ & Tinggi \\
\hline Kontrol & 0,534833796 & $53,43 \%$ & Sedang \\
\hline
\end{tabular}

Pada Tabel 6, diketahui bahwa nilai

$\mathrm{N}-$ Gain kemampuan komunikasi matematis siswa baik kelas eksperimen dan kelas kontrol mengalami peningkatan. Kelas eksperimen diperoleh N-Gain $70,12 \%$ termasuk kategori tinggi, sedangkan kelas kontrol diperoleh N-Gain $53,43 \%$ kategori sedang.

Kemampuan komunikasi matematis ini didukung oleh wawancara setelah dilaksanakannya posttest untuk mengetahui perbedaaa model pembelajaran Inside Outside Circle dilaksanakan di kelas eksperimen apakah lebih baik dari kelas kontrol yang menggunakan moodel pembelajaran konvensional.

Beberapa siswa dipilih sebagai sampel untuk dilakukan wawancara. Maka maka terpilih ada 2 siswa dari kelas eksperimen dan ada 2 siswa dari kelas kontrol yaitu pengambilan subjek diambil secara acak. Untuk subjek DAY dan MFI dari kelas eksperimen sudah mampu untuk menunjukkan indikor kemampuan komunikasi matematis yaitu drawing, mathematical expressions, dan writtent text, meskipun terkadang ada yang salah penempatannya. Sedangkan untuk subjek HSH dan KNA dari kelas kontrol belum terlalu mampu untuk menunjukkan indikor kemampuan komunikasi matematis yaitu drawing, mathematical expressions, dan writtent text. 
Dapat disimpulkan bahwa sebagai hasil yang diharapkan dan untuk menjawab rumusan masalah sesudah dilakukan analisis terhadap hasil nilai pretest maka perlu juga dilakukan pengujian pada nilai posttest. Rata-rata hasil belajar siswa kelas eksperimen adalah 77,67 dan kelas kontrol 70,95. Untuk membuktikan kevalidan dari perhitungan tersebut perlu uji normalitas, uji homogenitas dan uji hipotesis. Hasil perhitungan uji normalitas data postes pada kelas eksperimen diperoleh 0,107 nilai signifikan $0,107 \geq 0,05$, dan kelas kontrol diperoleh 0,053 nilai signifikan $0,053 \geq$ 0,05 karena nilai signifikan dari data kelas eksperimen lebih besar dari taraf signifikan 0,05, maka data kelas eksperimen dan kelas kontrol berdistribusi normal. Dari uji homogenitas data posttest diperoleh signifikan $=0,132$. Sehingga nilai signifikasn $=0,132 \geq 0,05$. Karena nilai signifikan dari data tersebut lebih besar dari taraf signifikan 0,05 maka data tersebut dinyatakan homogen.

Hasil perhitungan uji hipotesis posttest bahwa nilai sig (2-tailed) atau $P_{\text {value }}$ adalah 0,03 , sehingga dapat dituliskan nilai sig (2-tailed) atau $P_{\text {value }}>$ taraf $\quad$ signifikan $(0,05=5 \%)=$ $0,03<0,05$. Ini berarti bahwa nilai $P_{\text {value }}$ lebih kecil dari pada taraf signifikan $5 \%$. Dengan demikian, $H_{0}$ ditolak dan $H_{1}$ diterima, yang dapat disimpulkan bahwa terdapat perbedaan yang signifikan antara rata-rata posttestkemampuan komunikasi matematis yang diajar dengan menggunakan Model Pembelajaran Inside Outside Circle dengan menggunakan media CBC (Cube Beam Color) dengan siswa yang diajar dengan menggunakan pembelajaran konversional pada materi Kubus dan Balok.

Adanya kelas kontrol sebagai kelas pembanding memperkuat bahwa pembelajaran matematika dengan menggunakan Model Pembelajaran Inside Outside Circle (IOC)lebih efektif digunakan dari pada pembelajaran konvensional. Dengan demikian, $H_{0}$ ditolak dan $H_{1}$ diterima, yang artinya terdapat perbedaan yang signifikan antara kemampuan komunikasi matematis yang diajar dengan menggunakan Model Pembelajaran Inside Outside Circle dengan menggunakan media CBC (Cube Beam Color) dengan siswa yang diajar dengan menggunakan pembelajaran konversional. Sehingga dapat diinterpretasikan bahwa Model Pembelajaran Inside Outside Circle (IOC) lebih baik digunakan dalam pembelajaran matematika dalam meningkatkan kemampuan komunikasi matematik siswa dibandingkan Model Pembelajaran konversional. 
Ada beberapa hal yang mungkin menyebabkan adanya perbedaan rata-rata kemampuan komunikasi matematik siswa antara kelas eksperimen deng kelas kontrol, yakni model pembelajaran di kelas.

Pada kelas eksperimen dilakukan pembelajaran dengan Model Pembelajaran Inside Outside Circle dengan menggunakan media CBC (Cube Beam Color). Model pembelajaran ini menfasilitasi latihan berbahasa secara lisan dan tulisan.

Kelas eksperimen dan kelas kontrol mengalami (peningkatan) kemampuan komunikasi matematis siswa. Kelas eksperimen diperoleh N-Gain 0,7012 $\geq$ 0,70 termasuk kategori tinggi, edangkan kelas kontrol diperoleh N-Gain 0,0,5348 $\geq$ $0,70 \geq 0,30<70$.

Pada kelas eksperimen dilakukan pembelajaran dengan menggunakan model pembelajaran Inside Outside Circle (IOC). Model pembelajaran Inside Outside Circle (IOC) merupakan salah satu dari model yang menanggani masalah komunikasi secara langsung. Dengan melibatkan keterampilan kognitif pada setiap tingkat dari model ini sehingga mendorong siswa untuk belajar kreatif. Disamping prores kreatif digunakan pula proses bermacammacam arah dan menghasilkan banyak alternatif penyelesaian dan proses berpikir mencari jawaban tunggal.
Model pembelajaran Inside Outside Circle (IOC) ini dapat membantu siswa untuk mengkomunikasikan suatu ide matematika secara lisan maupun tulisan serta dapat membantu siswa untuk menemukan informasi baru dari kelompok lain sehingga siswa dapat membandingkan dan menggolah informasi tersebut menjadi lebih baik agar mudah difahami dan mudah untuk diingat.

\section{KESIMPULAN}

Berdasarkan hasil analisis data setelah dilaksanakannya penelitian tentang Model Pembelajaran Inside Outside Circle (IOC) dengan Menggunakan Media CBC (Cube Beam Color) Untuk Meningkatkan Kemampuan Komunikasi Matematis Siswa Pada Pokok Bahasan Kubus Dan Balok, dapat disimpulkan bahwa:

1. Terdapat perbedaan yang signifikan antara kemampuan komunikasi matematis siswa yang diajar menggunakan model pembelajaran kooperatif Inside Outside Circle (IOC) dengan menggunakan media $\mathrm{CBC}$ (Cube Beam Color) dan kemampuan komunikasi matematis siswa yang diajar menggunakan Pembelajaran Konvensional dalam pembelajaran kubus dan balok. 
2. Kemampuan komunikasi matematis siswa yang diajar menggunakan model pembelajaran Inside Outside Circle (IOC) dengan media CBC (Cube Beam Color) lebih baik dari pada dengan kemampuan komunikasi matematis siswa yang ajar mengunakan Pembelajaran Konvensional dalam pembelajaran kubus dan balok.

\section{DAFTAR PUSTAKA}

Ansari. (2016). Komunikasi Matematik Strategi Berfikir dan Manajemen Belajar Konsep dan Aplikasi. Banda Aceh: Pena.

Harapan, E. \& Ahmad, S. (2014). Komunikasi Antarpribadi, Jakarta: Penerbit PT.Rajagrafindo Persada. Hendriana, H., Rohaeti, E.E., Sumarmo, U. (2017). Hard Skills dan Soft Skills Matematika Siswa. Bandung: PT Refika Aditama.

Khaeruddin. (2018). Penerapan Model Pembelajaran Kooperatif Tipe Inside Outside Circle (IOC) Untuk Meningkatkan Hasil Belajar Siswa. Skripsi. Sarjana Mataram: Fakultas FTK UIN Mataram.

Menteri Pendidikan Nasional Republik indonesia. (2006). Standar Isi
3. Terdapat peningkatan kemampuan komunikasi matematis siswa yang diajar menggunakan model pembelajaran kooperatif Inside Outside Circle (IOC) dengan menggunakan media CBC (Cube Beam Color) dan kemampuan komunikasi matematis siswa yang diajar menggunakan Pembelajaran Konvensional dalam pembelajaran kubus dan balok.

untuk Satuan Pendidikan Dasar dan Menengah. Jakarta.

Rachmayani, D. (2014). Penerapan Pembelajaran Reciprocal Teaching untuk Meningkatkan Kemampuan Komunikasi Matematis dan Kemandirian Belajar Matematika Siswa. Jurnal Pendidikan UNSIKA. Vol. 2(1), pp. 13-23.

Shoimin, A. (2014). 68 Model Pembelajaran Inovatif dalam Kurikulum 2013. Yogyakarta: ArRuzz Media.

Sugiyono. (2014). Metode Penelitian Pendidikan Penelitian Kualitatif, Kuantitatif dan $R \& D$. Bandung: Alfabeta. 